\title{
산업발전과 일자리 창출: 한국의 경험과 개도국에 대한 시사점
}

목 차

서론: 산업발전과 고용구조 변화

1. 산업발전이 경제발전으로 이어지는 메커니즘

2. 산업 및 경제발전의 일반적 패턴

3. 한국의 산업 및 경제발전 단계

4. 산업인력 공급을 위한 제도와 정책

5. 개도국에 대한 시사점

\section{서론: 산업발전과 고용구조 변화}

노동은 생산요소의 하나로 재화와 용역의 생산에 참여하고 그 대가로 임금이라는 형태의 소득을 취득하게 된다. 재화와 용역을 생산하는 주체는 기업이다. 따라서 노동력에 대한 수요는 기업의 흥망성쇠에 크게 의존한다. 또한 시장경제에서 기업의 성과나 성패는 자신이 생산하는 재화와 용역이 시장에서 이윤을 남기고 판매되느냐에 달려있기 때문에 결국 기업의 경쟁력과도 직결되어 있다.

기업의 성과나 성패는 기업이 속해 있는 산업, 나아가 산업이 속해 있는 국민경제 전체의 조건에도 크게 의존한다. 결국 기업이 생산하는 재화나용역에 대한 수요는 산업이나 국민경제, 나아가 세계경제의 조건에 크게 달려있기 때문이다.

따라서 거시 경제적 차원에서 고용을 연구하는 일은 노동에 대한 수요자인 기업, 나아가 산업 및 국민경제 전체에 대한 연구를 포함하지 않을 수 없다. 결국 고용의 양과 질적 특성은 기업, 산업, 국민경제의 발전과 밀접히 연관되어 있다. 특히 기업이나 산업과 같이 미시적 수준의 특성이 고용과 국민경제 전체의 발전 사이의 관계를 어떻게 매개하는지 이해하는 것이 중요하다. 더욱이 자본주의 
경제에서는 어떤 의미에서 노동은 ‘수동적'인 위치에 있다. 시장에서 산업 및 기업의 성과 및 성패에 따라 노동에 대한 수요가 크게 영향을 받기 때문이다. 기업-산업-국민경제 전체로 이어지는 상호의존관계 ${ }^{1}$ 의 성격에 따라 고용의 양과 질적 성격이 크게 영향을 받는다는 이야기다.

특히 개도국의 경제발전은 급격한 구조변화를 동반하는 것이 특징인데, 이 구조변화의 성격에 따라 고용의 양과 질은 물론 궁극적으로는 국민경제 전체의 성장 속도나 지속가능성 등도 영향을 받는다. 특히 구조변화의 관점에서 한국의 경제발전을 특징짓는 것은 역시 산업화 및 산업고도화라고 해야 할 것이다.

본고는 한국 산업발전 과정의 특징을 살펴보고 이 특징이 고용의 양과 질적 특성, 특히 고용구조에 어떻게 반영되었는지 살펴볼 것이다. 특히 산업화의 도전에 직면해 있는 개도국에 대한 시사점을 얻는 것이 목적이기 때문에 탈산업화가 진행된 최근보다는 산업화를 통해 경제발전이 이루어진 1980년대 말까지 기간에 초점을 맞춘다. 이 과정은 결국 산업발전-경제성장(발전)을 통한 빈곤감소의 과정이기도 하다. 마지막으로 고용구조 변화에 반영된 한국의 경험이 현재 개도국의 산업발전과 고용창출 전략에 주는 시사점을 도출하고자 한다.

\section{1. 산업발전이 경제발전으로 이어지는 메커니즘}

경제성장이 곧 빈곤 감소는 아니지만2) 경제성장이 빈곤 감소에 유리한 조건을 제공할 수는 있다. 또한 $\mathrm{GDP}$ 가 감소하거나 성장이 느린 상황에서 빈곤감소를 달성하기는 아주 어려운 일이다.

한국 경제발전이 산업화를 통해 이루어졌다면 산업화가 어떻게 경제발전으로 이어지는지 그 구체적 메커니즘을 이해할 필요가 있다. 특히 고용 및 일자리가 어떤 경제부문에서 창출되는가, 따라서 부문별, 산업별 고용구조가 어떻게 변화하는가는 경제구조 변화의 핵심적 측면이며, 이 구조변화의 방향에 따라 경제발전의 속도와 방향도 크게 영향을 받기 때문이다.

이와 같이 경제의 구조적 측면을 강조하는 것은 경제부문이나 산업별로 일자리 창출, 생산성 향상, 수출, 혁신 등 다양한 측면에서 경제 전체의 성장은 물론 소득분배 등 경제발전의 다양한 측면에 미치는 영향이 동일하지 않다는 것을 의미한다. 즉 국민경제 전체의 성장 동력이 될 수 있는 잠재력이 산업별로 큰 차이가 있다고 볼 수 있다.

유럽 선진국으로부터 시작되어 북미, 남미, 아시아로 확산되어온 산업화의 역사는 산업, 특히 제조업이 경제발전 초기 단계에 성장 동력의 역할을 한다는 것을 보여준다. 선진국에서 제조업의

1) 이러한 구분은 미시-메조(중간)-거시의 세 수준에 대응한다. 이 의존관계는 기업의 합(aggregation)이 산업을 구성하고, 산업의 합이 국민경제를 구성하는 bottom-up의 관계만을 의미하지 않는다. 국민경제 전체의 조건이 산업별 발전 조건, 나아가 각 산업 내 기업의 발전 조건에 영향을 미치는 top-down의 관계도 역시 작용한다.

2) $\mathrm{GDP}$ 가 증가하더라도 소득의 분배 방식에 따라 빈곤은 늘어날 수 있다. 
고용 비중이 떨어지면서 탈산업화 현상이 일반화된 1970년대 이후에도 여전히 개도국의 경제발전은 산업화에 크게 의존하고 있다.

산업, 특히 제조업은 어떤 특성 때문에 경제성장의 동력 역할을 할 수 있는가? Kaldor로부터 시작된 경제학 전통에 따르면 세 가지 법칙에 따라 제조업의 성장이 경제 전체의 성장에 기여한다. 첫째 법칙은 제조업의 성장률이 높을수록 경제 전체의 성장률도 높아진다는 칼도 제 1 법칙이다. 둘째 법칙은 베르둔 법칙으로 알려진 것으로, 제조업 생산이 증가할수록 제조업의 노동생산성이 높아진다는 것이다. 셋째 법칙은 경제 전체의 생산성 증가도 제조업 생산 및 고용 증가와 양의 상관관계를 갖고 있고 비제조업 고용과는 음의 상관관계를 갖고 있다는 것이다. ${ }^{3)}$ 이러한 법칙이 현실 경제에 적용된다면 제조업은 다른 산업과는 달리 경제전체의 성장 동력으로 역할을 할 수 있는 특징을 가진다고 할 수 있다.

그렇다면 제조업의 어떠한 특성이 이러한 역할을 가능하게 하는가? 우선 제조업은 다른 산업과는 달리 전후방 연관효과(backward and forward linkage effects)가 크다. 예컨대 자동차 제조업의 발전은 후방산업인 철강 및 플라스틱 소재 산업의 발전은 물론 자동차를 이용하는 각종 전방산업 (주로 서비스)의 발전을 유도하는 효과가 크다. 둘째 제조업은 생산규모의 증대가 생산단가를 낮추는 규모의 경제가 강할 뿐만 아니라('정태적 규모의 경제’), 생산 활동의 반복 과정에서 새로운 노하우 및 기술이 축적되는 실행을 통한 학습(learning by doing)이 보다 크게 일어난다(‘동학적 규모의 경제’). 결국 제조업 생산이 증가할수록 농업이나 서비스업에 비해 제조업 생산성 상승 속도가 더 높아진다는 뜻이다. 또한 경제 전체에 영향을 미치는 기술발전 중 상당부분이 제조업에서 일어난다. 제조업에서 일어난기술발전이 새로운 투입물이나새로운 노하우의 형태로 다른산업으로 확산됨으로써 경제 전체의 효율성을 높인다. 마지막으로 제조업은 농업이나 서비스업에 비해 교역가능성, 따라서 수출가능성이 높다. 개도국 경제발전의 고질적인 문제 중 하나인 외화의 부족이라는 제약을 극복하는데 수출 제조업의 발전이 크게 기여할 수 있다는 점도 제조업이 경제발전에 기여할 수 있는 중요한 측면이다. ${ }^{45)}$

3) F. Trenenna(2009), "Characterising deindustrialization: an analysis of changes in manufacturing employment and output internationally", Cambridge Journal of Economics, 33, p. 435

4) 풍부한 천연자원을 보유한 개도국은 자원가격이 상승하는 시기에 외환의 제약으로부터 벗어날 수 있는 장점이 있지만, 그로 인하여 제조업의 경쟁력이 떨어지는 등 제조업 발전에는 불리한 환경이 만들어진다는 단점도 있다. 풍부한 자원이 축복인가 저주인가를 둘러싼 논쟁은 천연자원이 경제발전에 대해 갖는 이러한 이중적 관계를 반영한다.

5) F. Trenenna(2009), p. 436 


\section{2. 산업 및 경제발전의 일반적 패턴}

\section{1) 산업 및 경제발전의 일반적 패턴}

(1) 역 U자 관계(inverted U curve)

제조업의 일자리 창출 역할은 경제발전과 함께 변화한다. 한편으로는 전체 생산에서 제조업이 차지하는 비중이 변화하고, 다른 한편으로는 기업이 생산성 향상을 위해 새로운 기술이나 공정에 투자를 확대하는 과정에서 제조업의 고용 비중이 변화할 수 있기 때문이다. 전체 고용에서 제조업이 차지하는 비중이 경제발전 과정에서 어떻게 변하는지 보여주는 이러한 관계는 일반적으로 역 $\mathrm{U}$ 자 관계를 띠는 것으로 알려져 있다. 즉 일반적으로 경제발전 초기에는 경제성장과 함께 제조업의 고용비중이 증가하는 경향이 있지만, 일인당 소득이 약 만 달러를 넘어서서 중상위소득국에 근접한 후부터는 경제성장과 함께 제조업 고용비중이 떨어지는 탈산업화가 일어난다는 것이다.)

일인당 생산액과 제조업 생산 비중 사이의 일반적 관계를 나타내는 아래 <그림>에 따르면 개도국이 중상위소득국으로 도약하는 데 제조업 발전, 다시 말해 산업화가 결정적인 역할을 한다.

\section{<그림 1> 경제성장에 따른 제조업의 생산비중 변화}

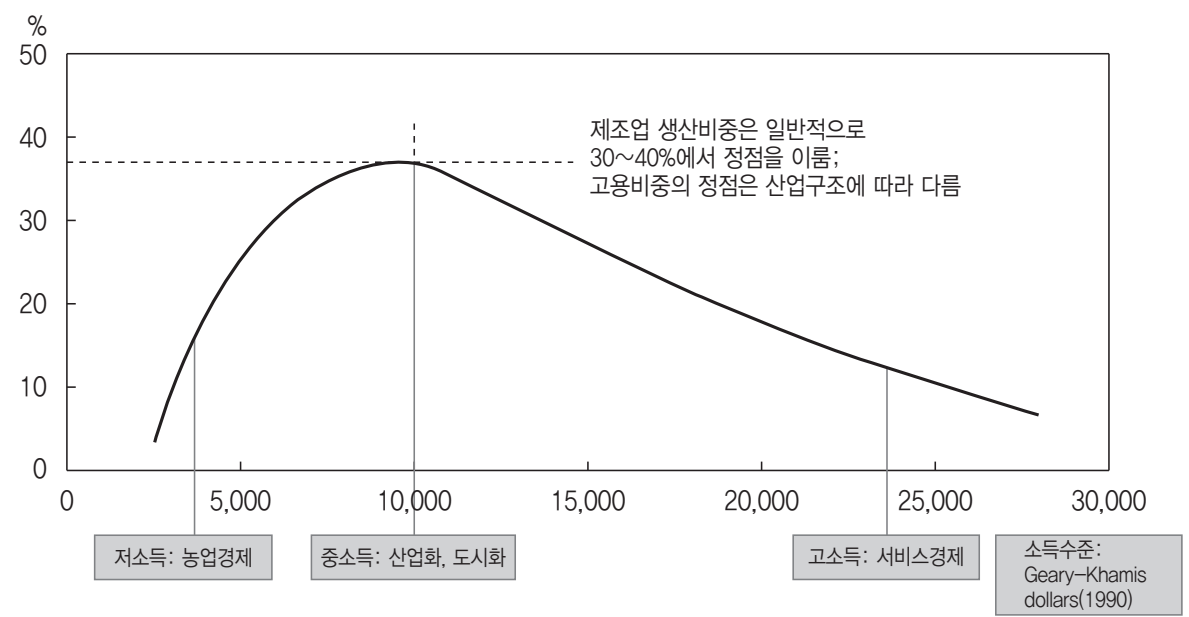

출처: MGI(2012), Manufacturing the future: the next era of global growth and innovation, p. 19

6) $M G I(2012)$, Manufacturing the future: the next era of global growth and innovation, p. 8 
물론 제조업 고용의 양적 증가와 함께 제조업 내부의 업종 및 고용의 구조 또한 끊임없이 변화한다. 산업고도화의 여러 가지 유형을 구분하는 시도는 제조업 고용비중의 변화뿐만 아니라 제조업 내부의 업종별 구성 변화도 역시 산업 및 경제발전과 밀접히 연관되어 있다는 것을 보여준다. Ernst(2001) 는 산업고도화의 다섯 가지 유형을 구분하고 있는데, 산업 및 경제발전은 이 다섯 가지 측면 모두에서 고도화가 일어나는 과정이기도 하다. 첫째 유형의 고도화는 산업간 고도화이다. 경공업과 같이 부가가치가 낮은 산업으로부터 부가가치가 높은 중화학공업 등 중심으로 산업구조가 변화하는 현상을 말한다. 둘째, 생산요소 상의 고도화이다. 천연자원이나 미숙련 노동력과 같이 주어진 생산요소에 주로 의존하던 생산에서 물적 자본이든 인적 자본이든 생산된 자본에 보다 크게 의존하는 생산으로, 나아가 사회적 자본과 같이 무형의 자본에 크게 의존하는 생산으로 중심이 이동하는 현상을 의미한다. 셋째 유형의 고도화는 수요, 특히 소비구조상의 변화로 필수재 중심의 소비패턴에서 소득증가와 함께 이전에는 사치재로 구분되던 제품의 대량 소비가 이루어지는 방식으로 소비패턴이 변화하는 현상을 지칭한다. 넷째, 가치사슬의 다양한 단계 중 부가가치가 낮은 활동에서 고부가가치 활동으로 중심이 이동하는 기능적 고도화이다. 산업이나 업종에 따라 가치사슬의 구성이 다르기 때문에 모든 업종에 걸쳐 기능적 고도화가 동일한 방식으로 일어난다고 할 수는 없을 것이다. 하지만 개도국의 경우 가치사슬 중 저부가가치 활동을 통해 생산 활동에 참여하여 점차 고부가가치 활동 또는 기능으로 참여영역을 확대하는 것이 보다 일반적인 산업발전 과정이다. 마지막 유형은 특히 천연자원에 크게 의존하는 자원부국에 적용되는 유형으로 전후방 연관 산업으로의 발전이다. 자원채굴로부터 시작하여 채굴을 지원하는 각종 서비스 산업의 발전(후방연계)이나 채굴한 자원의 가공 산업을 발전하는 변화 (전방연계)의 예가 그것이다.7) 이와 같이 다섯 유형에 걸쳐 일어나는 산업의 고도화가 고용구조의 변화에 결정적으로 영향을 미친다는 것은 재론할 여지가 없을 것이다. 나아가 제조업 고용의 양적 증가만이 아닌 제조업 고용 내부의 구조적 특징의 변화도 고용과 경제성장을 연결하는 중요한 매개항 임을 강조해야 할 것이다.

\section{(2) 선진국의 산업구조 변화 경험}

선진국의 역사적 경험은 제조업 고용과 경제성장간 역 U자 관계가 대체로 적용된다는 것을 보여준다. 아래 <그림>에서 보듯이 주요 선진국의 경우 1970년을 전후하여 제조업의 고용비중이 지속적으로 감소하기 시작하는 탈산업화가 시작되었다. 이와 동시에 서비스업의 고용 비중은 상승한다.

7) (D. Ernst, 2001, “Global Production Networks and Industrial Upgrading: a Knowledge-Centered Approach”, East-West Center Working Paper no. 25, p. 4) 
<그림 2> 주요 선진국 민간부문 고용에서 제조업, 서비스업이 차지하는 비중 변화

(단위: \%)
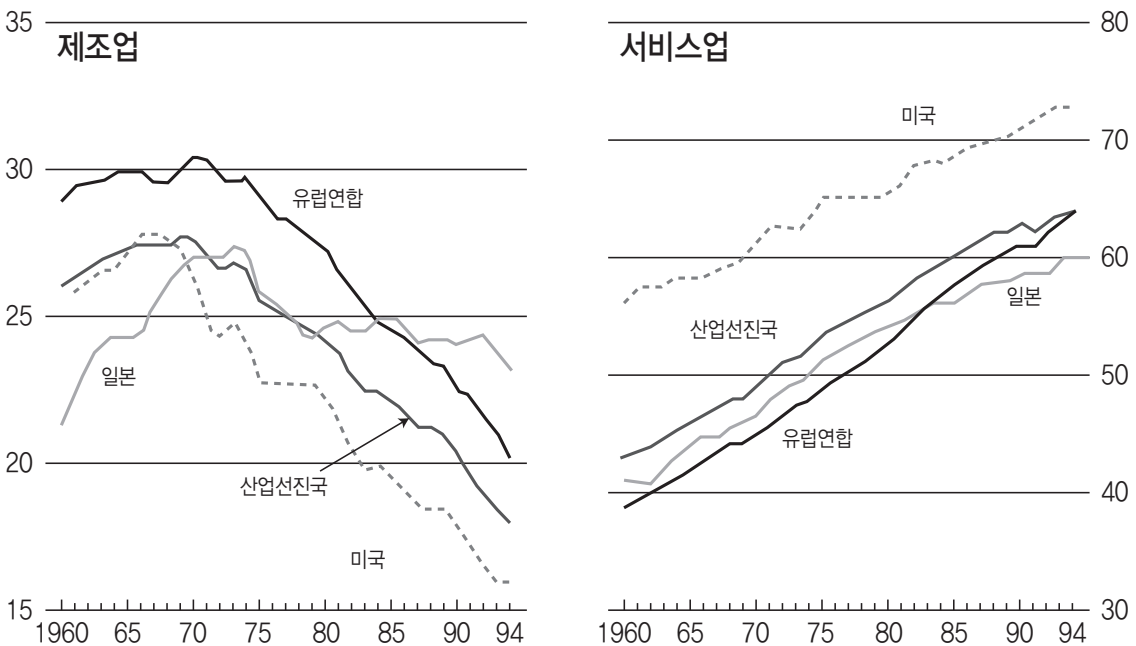

출처: R. Rowthorn and R. Ramaswamy(1997), “Deindustrialization: causes and implications”, IMF working paper, WP/97/42, p. 8

이것은 다른 한편으로는 1970년대 이전까지 선진국에서도 경제성장이 제조업 비중의 증가를 동반하면서 이루어졌다는 것을 의미한다. 선진국의 경우 거의 예외 없이 탈산업화가 지배적인 경향이라고 하더라도 적어도 중상위소득국에 도달하기까지 제조업의 발전은 경제성장에 기여할 수 있다는 점은 부정할 수 없으며, 따라서 개도국의 경제성장을 위해서는 여전히 산업, 특히 제조업의 발전이 중요한 역할을 할 수 있다는 것을 의미한다.

경제발전이 특정 수준을 넘어서면 탈산업화가 지배적인 경향이라고 하더라도 제조업 고용 및 부가가치 비중 감소의 속도는 나라에 따라 큰 차이가 있다. 아래 <그림>에서 보듯 1970년 이후 주요 선진국은 예외 없이 제조업 고용감소를 경험하지만 영국과 미국은 상대적으로 빠르게 감소하는 반면 일본이나 이탈리아는 상대적으로 느리게 탈산업화가 진행되었다. 2008년 시점에서 이탈리아, 독일, 일본은 상대적으로 높은 제조업 고용비중을 유지하고 있는 반면, 영국, 미국, 프랑스는 매우 낮은 비중이다. 
<그림 3> OECD 주요국 제조업 고용 비중 변화, 1971 2008

(단위: \%)

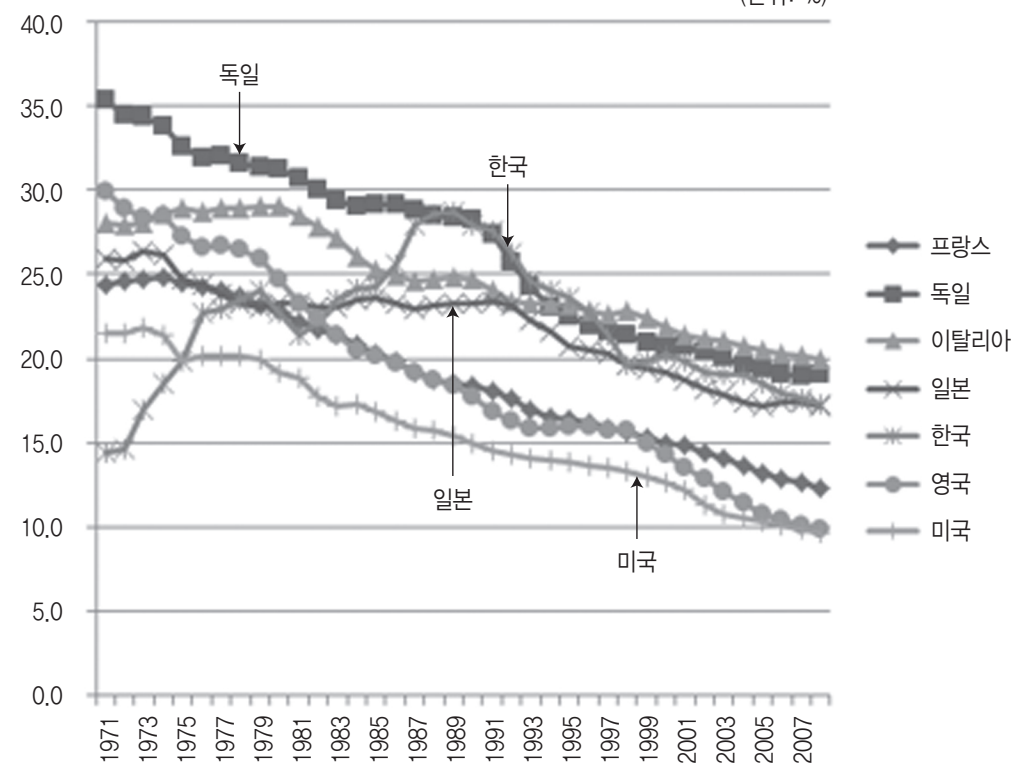

출처: $\mathrm{OECD}$

<그림 4> OECD 주요국의 제조업 부가가치 비중 변화, 1970 2008

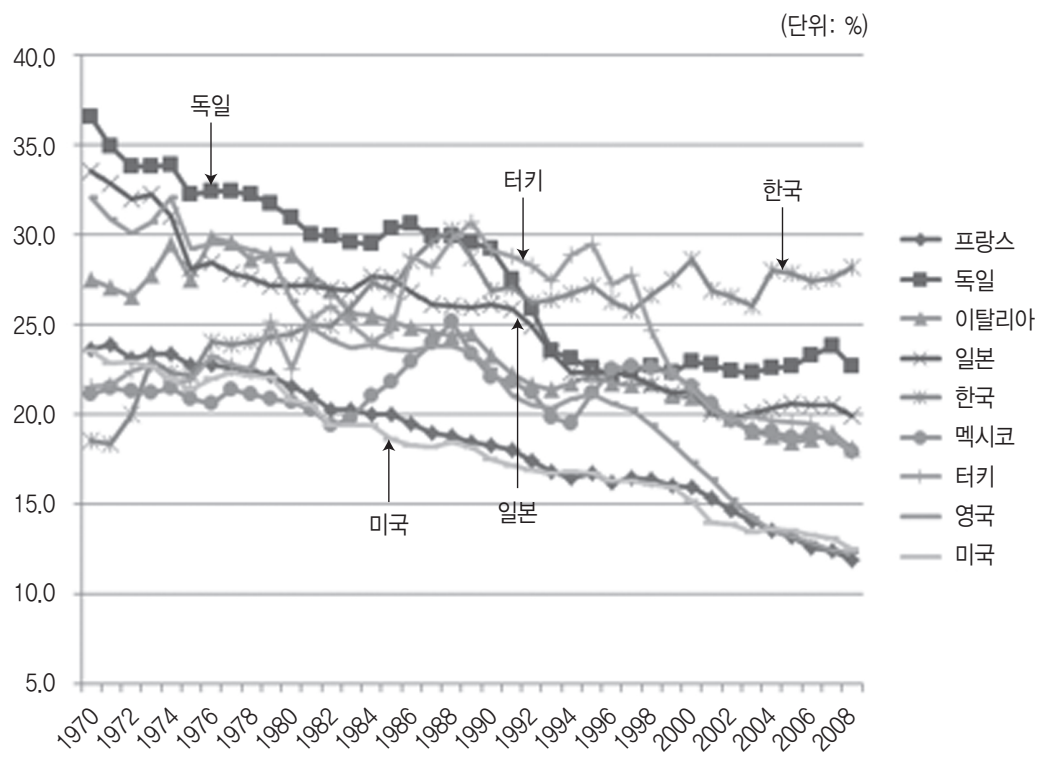

출처: $\mathrm{OECD}$ 


\section{3. 한국의 산업 및 경제발전 단계}

한국의 경제발전은 선진국과 비교하여 매우 짧은 기간에 이루어졌다는 '압축적' 성격을 제외하면 산업화를 통해 중진국으로 도약한 후 제조업 비중이 줄고 서비스 비중이 증가하는 '전형적인' 패턴에 따라 이루어졌다. 물론 이 압축적 성격 및 제조업 내부 구성을 보다 구체적으로 분석하면 보다 많은 차이가 드러나지만 긴 역사적 관점에서 볼 때 한국의 경제발전 패턴은 산업 및 경제발전의 일반적 패턴과 큰 차이가 없다.

결국 제조업 고용 및 생산 비중의 변화를 기준으로 한국의 경제발전 과정은 세 단계로 구분할 수 있다. 첫째는 1980년대 말까지의 산업화 단계로 제조업의 고용 및 생산 비중이 동시에 빠르게 증가하면서 제조업의 성장 동력 역할이 가장 크게 발휘된 시기이다. 둘째 시기는 대체로 1990년대에 해당하는 시기이다. 1980년대 말 이후 제조업의 고용 비중은 계속 감소하는 경향을 보이지만, 1990년대 약 10 년간 제조업 생산비중은 약간 감소하거나 정체상태에 머문다. 세 번째 시기는 대체로 2000년대 이후이나 보다 결정적으로 전환점을 제공한 것은 1998년 금융 경제위기(소위 'IMF 위기'로 불리는 외환 및 금융 위기)로 보아야 할 것이다. 이 세 번째 시기의 특징은 제조업 고용감소가 지속적으로 이루어지지만 부가가치 생산비중은 오히려 증가하는 “재산업화`ㄱㅏㅏ 이루어진 시기이다.9)

<그림 5> 제조업 부가가치 및 고용 비중 변화, 1963 2005

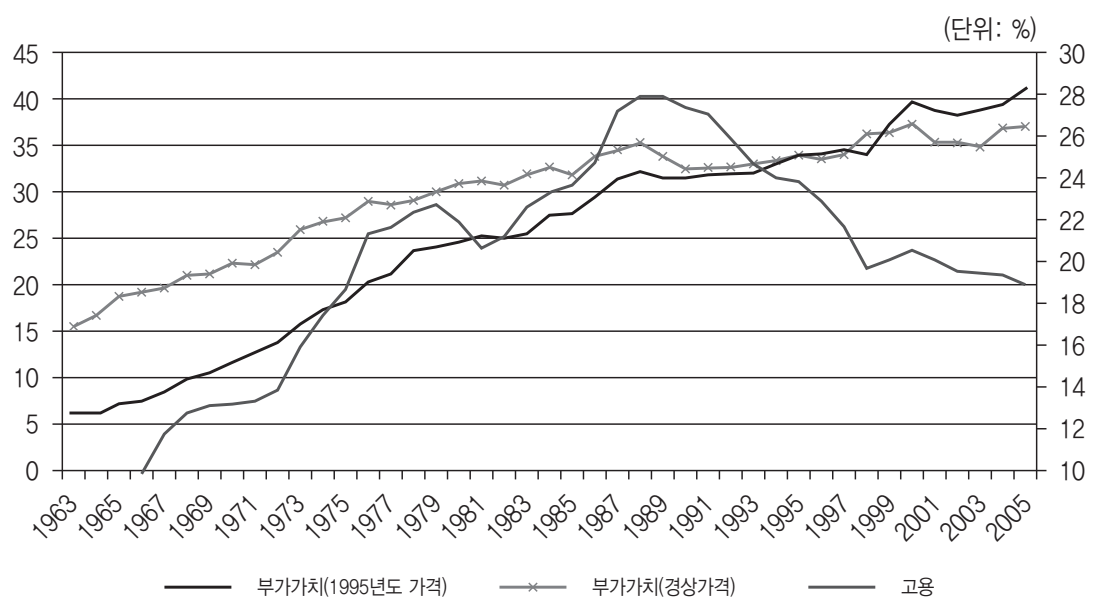

출처: Groningen Growth and Development Centre 10-sector database, June 2007, http://www.ggdc.net/ 주: 고용은 오른쪽 축

8) 일반적으로 탈산업화는 제조업 고용비중의 감소를 기준으로 하기 때문에 제조업 생산비중의 증가를 재산업화라고 할 수는 없다. 하지만 이 시기의 특수성을 강조하기 위해 제조업 생산비중의 증가 재산업화라고 부르고자 한다.

9) D. Y. Kang(2014), "Re-industrialization of the Korean economy: facts, causes, and implications", KRCS and CNRS, 미래에의 전략적 대응, 국제세미나 발표자료 
한국의 경우에도 1980 년대 말까지는 경제성장이 제조업의 고용비중 증가를 동반하지만 그 이후에는 오히려 제조업 고용감소가 빠르게 일어난다. 반면 제조업의 부가가치 비중의 변화 패턴은 고용 변화와는 다른 패턴을 그린다는 점에 주의를 기울일 필요가 있다. 제조업 생산(부가가치) 비중 역시 1980년대 말에 중요한 전환점을 맞는 것은 사실이다. 그러나 그때까지 거의 유사한 속도로 증가하던 생산비중이 정체기에 들어서고 2000년대를 넘어서면서 속도는 더디지만 오히려 증가하는 경향으로 변화한다는 점에서 고용비중의 감소와는 큰 차이를 보인다. 이와 같이 고용기준 탈산업화시기에 제조업의 생산비중이 증가한다는 것은 제조업 생산증가의 주요 원천이 생산성의 증가임을 알 수 있다. 실제로 2000년대 한국의 제조업의 노동생산성은 주요 선진국 중 가장 빠른 속도로 증가하였다. ${ }^{10)}$

<그림 6> 한국과 G7 국가의 취업자당 노동생산성 추이(2001=100)

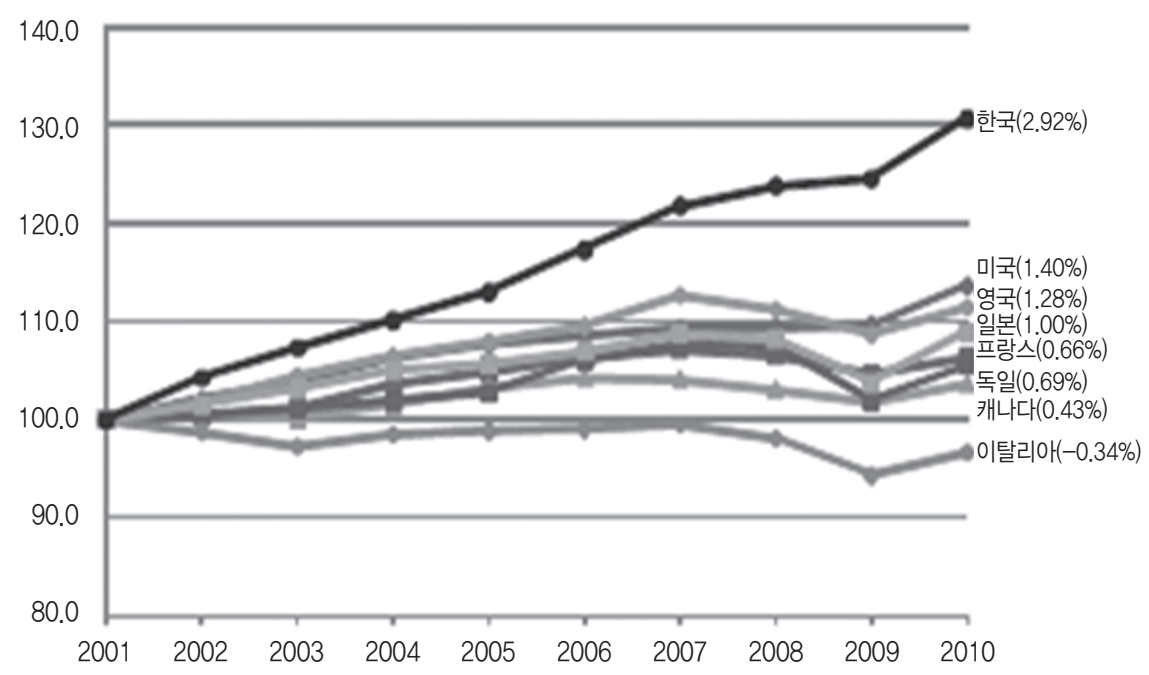

출처: 산업통상부(2014), "2011년도 노동생산성 국제비교"

주: ( )안 수치는 2001 2010년 동안 연평균 증가율

아래<그림>은 1963년부터 1992년까지 산업화를 통한 고속 경제성장이 이루어진 30년 동안 산업별 고용구조가 얼마나 급속하게 변화되어 왔는지를 잘 보여준다. 1963년 $63 \%$ 를 차지하던 농립어업의 고용비중은 1992년 14\%에 이를 때까지 급속히 감소하였다. 반대로 제조업과 사회간접자본 및 기타 서비스는 역시 매우 빠른 속도로 비중이 증가하여 1963년 각각 $7.9 \%, 28.3 \%$ 에서 1989년 각각 $27.8 \%, 52.1 \%$ 로 상승하였다. 앞에서 본 것처럼 제조업 고용 비중은 1989 년을 정점으로 하여 하락하기 시작하였지만, 사회간접자본 및 기타 서비스 비중은 여전히 증가하고 있다.

10) 산업통상부(2014), "2011년도 노동생산성 국제비교" 
<그림 7> 주요 산업부문별 고용구조의 변화, 1963 1992

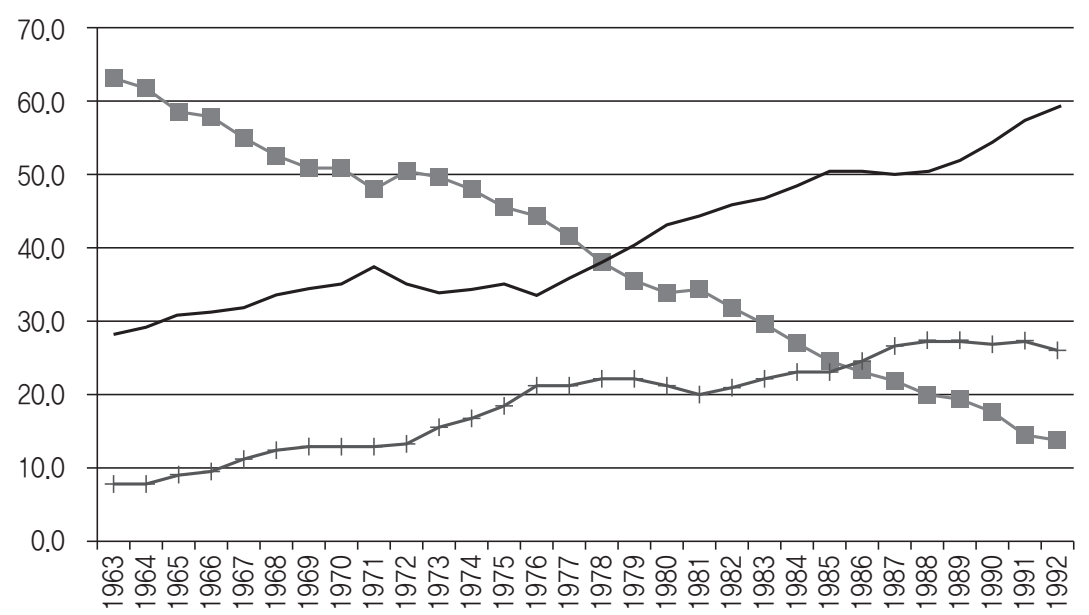

느농림어업 느 제조업 사회간접자본 및 기타서비스업

출처: 통계청

앞에서 거시적 차원에서 일어나는 산업간 고도화와 함께 각 산업 내에서도 동시에 고도화가 일어난다고 언급하였다. 산업 내 고도화가 어떤 방식으로 이루어지는지 1960년대 한국의 주요 수출산업이었던 가전, 신발, 의류 산업의 예를 통해 살펴보자.

Wortzel and Wortzel(1981) $)^{11)}$ 은 동북아시아 후발기업 발전의 공통 패턴을 마케팅 방식의 발전에 초점을 맞춰 분석하고 있다. 특히 이들이 분석하고 있는 산업은 가전, 신발, 의류인데 이들 제품은 노동집약도가 높은 산업으로 한국의 초기 산업화에서 주요 산업이었다. 따라서 그 다음 단계의 주요 산업인 자본집약적인 중화학공업의 후발기업 발전 패턴과는 상당한 차이를 보일 것으로 예상할 수 있고, 나아가 그 다음 단계인 기술 및 R\&D 집약도가 높은 산업의 발전패턴과도 상당한 차이가 있을 것으로 예상할 수 있다. 아무튼 이러한 순차적 과정을 거쳐 기업의 역량이 축적된다는 것을 보여주는 좋은 사례임에 틀림없다.

Wortzel and Wortzel(1981)은 마케팅 발전을 다섯 단계로 구분하고 있다. 첫 번째 단계에서 후발기업은 제품 디자인, 마케팅, 유통, 품질관리 등 대부분의 기능을 주로 외국계인 구매기업에 의존한다. 판매하는 것은 저비용 생산 서비스이다. 2 단계에서 5 단계로 발전하면서 후발기업은 점점 더 많은 복잡한 마케팅 역량을 축적하게 되며, 결국 독자적인 판매 및 마케팅 역량을 구축하기에 이른다. 5 단계에 이르면 후발기업은 독자적인 브랜드로 해외시장에 직접 판매하는 역량을 구축하고 더 이상 해외 바이어나 제조업체에 의존하지 않게 된다. ${ }^{12)}$

11) Wortzel and Wortzel(1981), Mike Hobday(1994), "Export-led technology development in the four Dragons: the case of electronics", Development and Change, vol. 25.

12) 전자산업의 경우 1970년대 말 경 제4단계에 도달하게 된다. 
한편 후발국 발전에서는 기술 선진국과는 달리 '학습’이 중요한 역할을 한다. 특히 후발국의 학습에 대한 연구는 기술적 노하우가 기업이나 관련 제도에서 어떻게 축적되는지에 초점이 맞춰져 있다. 기업이 제품, 공정 및 관련 조직구조 등의 역량(capabilities)을 어떻게 축적하는지가 중요한 질문이다. 후발국 학습에 대한 많은 연구는 학습이 생산역량에서 투자역량으로, 그리고 혁신역량으로 순차적으로 발전한다는 것을 보여준다. 따라서 앞서 분석한 마케팅 차원의 발전과정이 기술적 차원의 발전과정과 일정한 연관관계를 갖고 있을 것을 예상할 수 있다.

$<$ 표 1> 추격성장에서 시장과 기술의 병행발전

\begin{tabular}{|c|c|c|}
\hline & 기술발전단계(learning) & 시장발전단계 \\
\hline 1 & $\begin{array}{l}\text { 조립기술, } \\
\text { 기초적 생산역량, } \\
\text { 성숙기 제품 }\end{array}$ & $\begin{array}{l}\text { 수동적으로 수입업자에 대응, } \\
\text { 저비용 노동력을 이용한 조립, } \\
\text { 유통은 바이어에 의존 }\end{array}$ \\
\hline 2 & $\begin{array}{c}\text { 품질개선과 속도향상을 위해 점진적인 공정 개선, } \\
\text { 제품의 리버스 엔지니어링 }\end{array}$ & $\begin{array}{l}\text { 적극적인 생산서비스 판매, } \\
\text { 품질과 비용에 기초한 경쟁력, } \\
\text { 그러나 해외 바이어에 의존 }\end{array}$ \\
\hline 3 & $\begin{array}{l}\text { 전 생산기술 습득, } \\
\text { 공정혁신 개시, } \\
\text { 제품 디자인 역량 구축 }\end{array}$ & $\begin{array}{l}\text { 진전된 제품 판매, } \\
\text { 마케팅 부서 설립, } \\
\text { 해외 마케팅 개시, } \\
\text { 자체 디자인 제품 마케팅 }\end{array}$ \\
\hline 4 & $\begin{array}{l}\text { 제품 및 공정 R\&D 시작, } \\
\text { 제품 혁신 역량 강화 }\end{array}$ & $\begin{array}{c}\text { 공격적 제품 마케팅, } \\
\text { 해외 소매업자나 유통업자에 직접 판매, } \\
\text { 다양한 제품을 구비, } \\
\text { 자체 브랜드 마케팅 개시 }\end{array}$ \\
\hline 5 & $\begin{array}{l}\text { 경쟁력을 갖춘 R\&D 역량, } \\
\text { 시장의 수요와 연계된 R\&D, } \\
\text { 선진적 제품/공정 혁신 }\end{array}$ & $\begin{array}{c}\text { 공격적 자체브랜드 판매, } \\
\text { 고객 상대로 직접 판매, } \\
\text { 독립된 유통망, 직접 광고망, 강력한 시장조사기능 }\end{array}$ \\
\hline
\end{tabular}

출처: Wortzel and Wortzel(1981), Mike Hobday(1994), "Export-led technology development in the four Dragons: the case of electronics", Development and Change, vol. 25. 재인용

후발기업은 단순 조립 기술을 가지고 시장에 진입한 후 공정역량을 흡수하는 단계로 발전한다. 생산용량이 확대되고 고객기업 수가 확대됨에 따라 품질관리 및 생산속도 관리 역량의 강화도 요구된다. 그러나 발전 초기 단계에는 기술을 외부 원천에 의존한다. 그러나 수출확대의 기회가 확대되면서 생산과정에 대한 통제력이 점점 더 높아진다. 국내 기술진에 의한 핵심 생산기술의 흡수도 점차 확대된다.

이러한 과정에서 수출시장의 확대와 기업의 기술역량 축적이 상호작용하는 누적적 상호작용 (호순환)이 작동한다. 이렇게 제품 및 공정 역량의 획득이 확대됨에 따라 보다 고품질의 제품을 보다 확대된 고객에게 판매할 수 있게 된다. 이리하여 저비용 엔지니어링 및 경영 서비스가 중요한 경쟁우위의 원천인 단계로 발전한다. 제4단계에 도달할 때 쯤 되면 기업은 새로운 제품이나 공정을 개발할 수 있는 기술을 축적하게 된다. 제품 디자인, 품질관리 및 공정 엔지니어링 분야에서 기술적 
의존을 극복할 수준에 도달한다. 자본재를 공급하는 기업과 유기적 연계를 구축했을 수 있고 나아가 신제품이나 공정을 개발하기 위한 R\&D 역량을 구축했을 수도 있다. 마지막 단계인 5단계에는 보다 고도의 기술과 R\&D 역량을 구축한다.

앞의 단계적 고도화 과정에 대한 설명에서 유추할 수 있듯이 산업 내 고도화도 역시 고용구조의 변화에 반영된다. 그러나 산업별 고용구조의 변화와 달리 산업 내 고도화에 대응하는 고용구조의 변화를 통계적으로 확인하는 일은 쉽지 않다. 숙련 수준별 고용구조 변화가 이러한 산업고도화 개념에 어느 정도 적절히 대응할 것이다. 여기서는 직업별 고용구조의 변화를 살펴봄으로써 산업발전에 따른 고용구조 변화의 또 하나의 측면을 이해하고자 한다.

역시 농림수산직의 비중이 급속히 감소한다. 반면 생산직, 전문기술사무직, 판매서비스직은 고도 산업화 기간 동안 빠르게 증가한다. 생산직이나 판매서비스직이 1990년을 넘어서면서 더 이상 증가하지 않는 정체기에 들어간 반면 전문기술사무직의 비중은 그 이후에도 계속 증가를 멈추지 않고 있다. 이러한 직업별 고용구조의 변화는 거시적 측면의 산업별 고용구조의 변화를 반영하기도 하지만 동시에 산업 내 고도화를 반영하는 것이기도 하다. ${ }^{13)}$

\section{<그림 8> 직업별 고용구조의 변화}

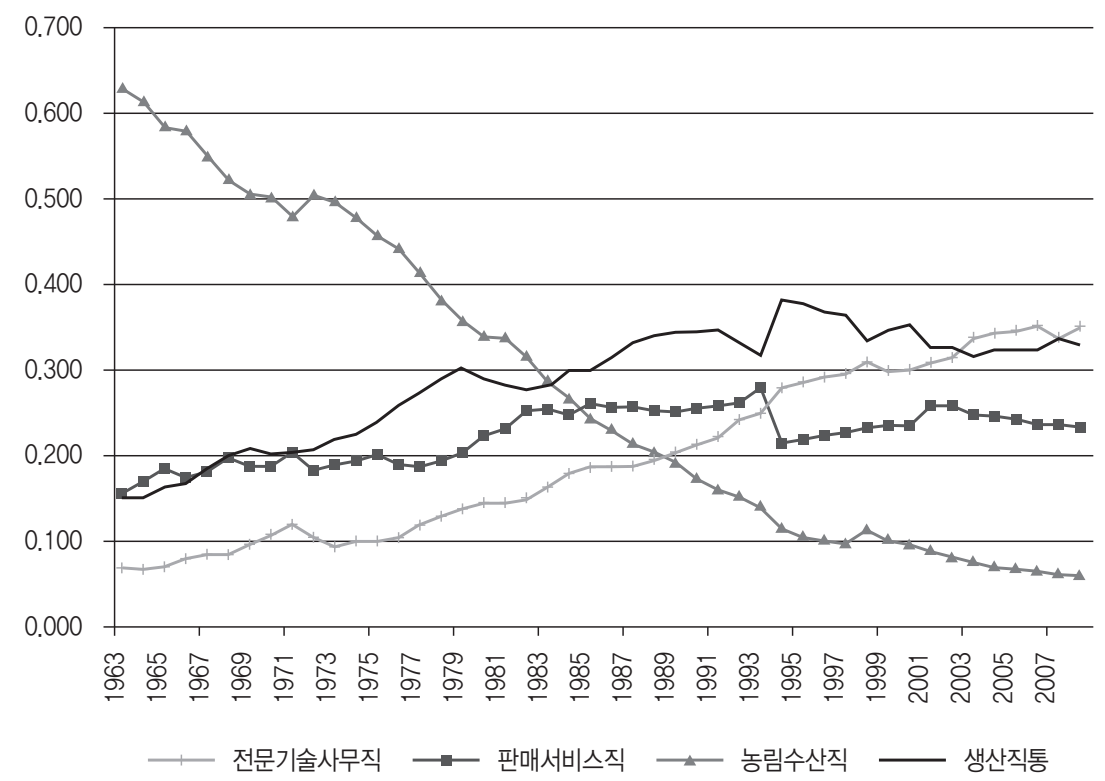

출처: 정택수(2013), “직업능력개발제도의 변천과 과제”, 산업연구원 회의자료

13) 산업고도화가 고용구조의 변화에 어떻게 반영되는지는 최근 발표된 기업연구소 및 연구전담부서 현황에서도 잘 드러난다. 2012년 현재 기업연구소는 3만개에 이르고 있고, 13 만여 개에 이르는 5 인 이상 제조업체 중 약 $23 \%$ 가 연구소를 운영하고 있다. 기업 연구소 신고 제도를 도입한 1981년 당시 연구원은 7000 명에 불과했으나 2012년 27만5000명으로 약 40배 증가했다. 박용현(2014), “기업연구소 3만개, 혁신의 패러다임 바꾸자", 매일경제신문 2014년 5월 8일자 
이 시기 산업별 고용구조의 변화는 총 고용량이 급속하게 증가하는 동시에 일어났다는 점에 주의할 필요가 있다. 이 고성장 산업화 30년 동안 총 고용은 1963년 759만 명에서 1,900만 명으로 약 $250 \%$ 증가했기 때문이다. 따라서 농림수산업의 고용비중이 계속 감소하기는 하지만 1970년대 중반까지 농립수산업의 총고용량은 크게 감소하지 않았고, 그 이후부터 절대 고용량이 감소하기 시작했다. 반면 제조업과 ‘서비스'14)는 고용 비중이나 절대량에서 모두 빠르게 증가하였다.

<그림 9> 주요 경제부문별 취업자 수 추이, 1963 1992

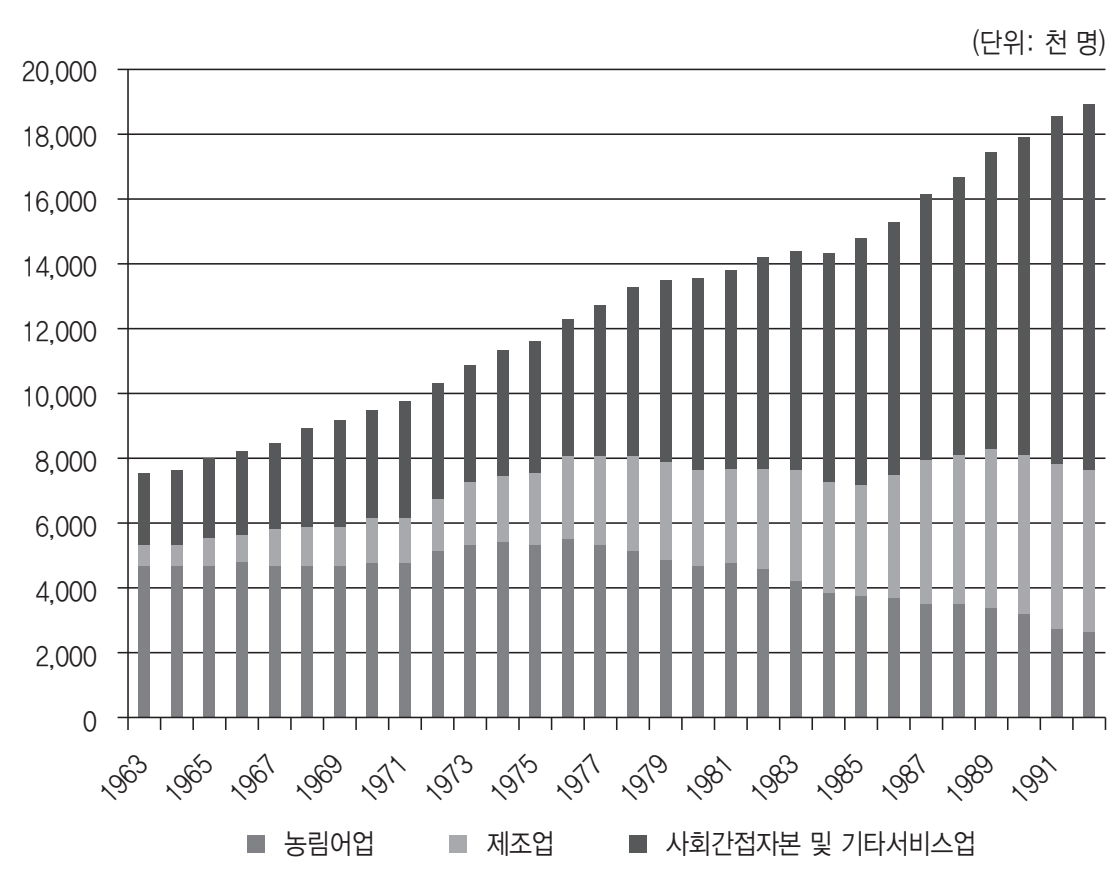

출처: 통계청

물론 이렇게 고용의 총량과 구조가 급속하게 변화된 이면에는 산업화라는 경제구조의 변화 및 산업화에 동반되는 도시화뿐만 아니라 1950년대 60년대 중반에 걸친 베이비붐이라는 인구학적 요인이 상호작용하는 복잡한 과정이 있다. 특히 베이비붐 세대가 노동시장에 진입하는 시점에는 청년층의 일자리 수요가 폭발적으로 늘어나는 인구 압력이 가중되기 때문에 이를 적절히 해소할 수 있는 출구를 발견하지 못하는 경우 사회 정치적 위기로 전이될 수 있다는 점에서 개도국에 주요한 도전이 아닐 수 없다. 반면 양질의 노동력이 대량으로 시장에 진입한다는 것은 경제발전의 가장 중요한 원천이 될 수 있다는 점에서 고도성장을 달성할 수 있는 기회를 준다. 한국은 이러한 인구 압력을 고도 경제성장의 원천으로 성공적으로 이용한 대표적 사례라고 할 수 있다.

14) 사회간접자본 포함 
이러한 인구학적 요인이 어떻게 경제성장에 기여할 수 있는지 이해하기 위해 다음과 같은 항등식을 이용할 수 있다. ${ }^{15)}$

1 인당 $\mathrm{GDP}=$ 실질 $\mathrm{GDP} /$ 총 인구 $=$ 실질 $\mathrm{GDP} /$ 총 근로자수 * 총 근로자수/경제활동인구수 * 경제활동인구수/ 15 세 이상 인구수 * 15 세 이상 인구수/총 인구수

1 인당 $\mathrm{GDP}=$ 노동생산성 * 취업률 * 경제활동참가율 * 경제활동가능인구 비중

또는 경제성장률 $=$ 인구증가율 +1 인당 $\mathrm{GDP}$ 증가율

$=$ 인구증가율 + 노동생산성 증가율 + 취업률 변화율 + 경제활동참가율 변화율 + 경제활동가능인구 비중 변화율

산업화 초기인 1960년대와 70년대 경제성장에 대한 인구증가의 기여도가 상대적으로 매우 높다. $63 \sim 70$ 년에는 $26 \%, 70$ 년대에는 $25 \%$ 에 이른다. 여기에 경제활동 가능인구의 비중 변화율이라는 요인을 추가하면 순수하게 인구증가와 인구구조의 변화에 의해 설명되는 경제성장률의 비중이 산업화 초기에 $30 \%$ 이상으로 매우 높다는 사실을 발견할 수 있다. 특히 1970년대에는 경제활동가능인구의 비중 변화가 전체 경제성상의 $23 \%$ 를 설명할 정도로 매우 높다. 이것은 이 시기 1950년대 60년대에 태어난 베이비붐 세대가 본격적으로 노동시장에 진입하면서 나타난 효과이다.

<표 2> 요인별 경제성장률 분해(연평균 변화율), 1963 2010(단위: \%)

\begin{tabular}{c|c|c|c|c|c|c|c}
\hline \multirow{2}{*}{ 기간 } & \multirow{2}{*}{$\begin{array}{c}\text { 경제 } \\
\text { 성장률 }\end{array}$} & \multirow{2}{*}{$\begin{array}{c}\text { 인구 } \\
\text { 증가율 }\end{array}$} & $\begin{array}{c}\text { 1인당 GDP } \\
\text { 증가율 }\end{array}$ & $\begin{array}{c}\text { 노동생산성 } \\
\text { 증가율 }\end{array}$ & $\begin{array}{c}\text { 취업률 } \\
\text { 변화율 }\end{array}$ & $\begin{array}{c}\text { ㄱㅕㅕ제활동 } \\
\text { 참가율 } \\
\text { 변화율 }\end{array}$ & $\begin{array}{c}\text { 경제활동가능 } \\
\text { 인구 비중 } \\
\text { 변화율 }\end{array}$ \\
\hline \multirow{2}{*}{$1963 \sim 1970$} & 8.9 & $\begin{array}{c}2.3 \\
(26.0)\end{array}$ & $\begin{array}{c}6.6 \\
(74.0)\end{array}$ & $\begin{array}{c}5.5 \\
(61.6)\end{array}$ & $\begin{array}{c}0.6 \\
(6.3)\end{array}$ & $\begin{array}{c}0.3 \\
(2.9)\end{array}$ & $\begin{array}{c}0.3 \\
(3.3)\end{array}$ \\
\hline \multirow{2}{*}{$1970 \sim 1980$} & 7.0 & $\begin{array}{c}1.8 \\
(25.4)\end{array}$ & $\begin{array}{c}5.2 \\
(74.6)\end{array}$ & $\begin{array}{c}3.5 \\
(49.6)\end{array}$ & $\begin{array}{c}-0.1 \\
(-1.1)\end{array}$ & $\begin{array}{c}0.2 \\
(3.4)\end{array}$ & $\begin{array}{c}1.6 \\
(22.8)\end{array}$ \\
\hline \multirow{2}{*}{$1980 \sim 1990$} & 8.4 & $\begin{array}{c}1.2 \\
(14.0)\end{array}$ & $\begin{array}{c}7.2 \\
(86.0)\end{array}$ & $\begin{array}{c}5.6 \\
(66.7)\end{array}$ & $\begin{array}{c}0.3 \\
(3.4)\end{array}$ & $\begin{array}{c}0.2 \\
(2.1)\end{array}$ & $\begin{array}{c}1.2 \\
(13.8)\end{array}$ \\
\hline \multirow{2}{*}{ 1990 2000 } & 5.9 & $\begin{array}{c}0.9 \\
(15.6)\end{array}$ & $\begin{array}{c}5.0 \\
(84.4)\end{array}$ & $\begin{array}{c}4.3 \\
(73.4)\end{array}$ & $\begin{array}{c}-0.2 \\
(-3.0)\end{array}$ & $\begin{array}{c}-0.2 \\
(2.7)\end{array}$ & $\begin{array}{c}0.7 \\
(11.2)\end{array}$ \\
\hline \multirow{2}{*}{ 2000 2010 } & 4.1 & $\begin{array}{c}0.5 \\
(12.2)\end{array}$ & $\begin{array}{c}3.6 \\
(87.8)\end{array}$ & $\begin{array}{c}2.9 \\
(70.8)\end{array}$ & $\begin{array}{c}0.1 \\
(1.9)\end{array}$ & $\begin{array}{c}0.0 \\
(-0.9)\end{array}$ & $\begin{array}{c}0.7 \\
(16.0)\end{array}$ \\
\hline
\end{tabular}

출처: 주동주 외(2013), 한국의 산업분야 ODA 역량과 추진 방안, 산업연구원, 세계경제사회연구원, 연구보고서 2013-696, p. 126

15) 인구구조의 경제성장에 대한 기여는 주로 아래 분석을 참고. 주동주 외(2013), 한국의 산업분야 ODA 역량과 추진 방안, 산업연구원, 세계경제사회연구원, 연구보고서 2013-696 
그러나 경제성장에 가장 크게 기여한 요인은 역시 노동생산성의 증가이다. 기여율이 $50 \%$ 아래로 떨어진 70년대를 제외하면 모든 시기에 60 70\%를 넘는 기여율을 보이고 있다. 개도국의 경우 노동생산성의 증가에 가장 크게 기여하는 것이 바로 산업화이다.

\section{4. 산업인력 공급을 위한 제도와 정책}

앞 절에서는 산업구조의 변화나 고도화로부터 유발되는 노동(력)에 대한 수요가 있다고 하더라도 필요한 인력을 필요한 시기에 공급할 수 없다면 산업구조의 변화나 고도화는 효율적으로 실현되기 어려울 것이다. 더욱이 노동(력)은 그 공급을 시장에만 의존하여 효과적으로 실현되기 어려운 특수한 성격을 갖고 있다. 특히 산업화와 산업고도화에 상응하여 양적으로나 질적으로 적절한 산업인력을 공급하는 효과적인 제도와 정책은 한국의 고도 산업화에 결정적인 기여를 했다. 바로 직업교육 및 직업훈련 제도 및 정책이 여기에 해당한다. 한국 정부는 1960 년대 초반 제 1 차 경제개발계획을 추진하는 시기부터 계획상에 직업훈련제도의 발전을 포함시켜 산업발전을 지원했다.

특히 산업화를 위한 기능인력 양성 제도의 역할이 컸다. 여기에는 두 가지 제도가 상호의존적이지만 구별되는 역할을 했다. 하나는 공식 교육기관을 통한 직업교육이며 다른 하나는 직업훈련이다. 공식 직업교육이 2 차 교육기관에서 장기에 걸쳐 기초 기능교육을 제공하는 데 반해 직업훈련은 현직 또는 장래의 노동자에게 단기에 걸쳐 기능 훈련을 제공한다. 이와 같이 직업교육과 훈련으로 양분된 체제가 한국의 기능인력 양성 제도의 특징 중 하나이다. 공식적 직업교육만으로는 산업이 요구하는 다양한 기능인력 수요를 충족할 수 없어 산업현장과 보다 깊이 연관된 직업훈련제도가 이 간극을 보완하는 역할을 한 것이다. ${ }^{16)}$ 한국에서는 직업교육기관으로 상고나 공고 등 실업계 고등학교가 중요한 역할을 했다. 반면 직업훈련을 위해서는 기술학교나 전문화된 직업훈련원 등이 보다 중요한 역할을 했다 ${ }^{17)}$.

1960 년대 후반의 제 2 차 과학기술육성계획을 살펴보면 기능인력 공급 정책은 주로 과학기술육성 계획에 포함되어 추진되었다. 경제개발계획이나 과학기술육성 계획 입안 과정에서 과학자, 엔지니어, 기능공 등 다양한 기능인력에 대한 수요가 도출되고 부족량이 확인되면 기능인력 범주별 부족량을 채우기 위한 정책과 필요한 제도 및 기관 설립이 추진되었다. 이러한 방식으로 중앙직업훈련원이 설립되어 기능인력 양성을 위한 교원의 훈련, 기능 테스트, 훈련 교재 작성의 역할을 맡도록 했고, 실업계 고등학교의 교육과정도 개편되었다.

또 하나의 대표적 사례를 들자면 1970년대 중화학공업 육성전략의 실현을 위한 기능인력 공급 정책이다. 1971년 정부는 중화학공업 육성을 핵심으로 하는 제3차 경제개발5개년계획(1972 1976)

16) Young-Sun Ra, et. al., (2012), Vocational training system for a skilled workforce, 2011 modulization of Korea's Development Experience, p. 83

17) 전게서, p. 83 
의 실현을 지원하기 위해 제 3 차 인적자원개발계획을 수립하였다 ${ }^{18)}$. 당시 계획의 초점은 핵심 산업인 중화학공업이 필요로 하는 노동력을 공급하는 데 맞춰졌다.

$<$ 표 3> 제2차 경제개발5개년계획 기간 동안 기능인력 수요 예측

(단위: 1,000 명)

\begin{tabular}{c|c|c|c|c|c|c}
\hline & 1967 & 1968 & 1969 & 1970 & 1971 & 함계 \\
\hline 총 수요 & 363.1 & 397.0 & 430.4 & 462.5 & 493.5 & \\
\hline 추가 수요 & 34.6 & 33.9 & 33.4 & 32.1 & 31.0 & 165.0 \\
\hline 실업계 고교 졸업자 수요 & 11.6 & 12.4 & 14.9 & 14.9 & 14.9 & 68.7 \\
\hline 직업훈련 수요 & 23.0 & 21.5 & 18.5 & 17.2 & 16.1 & 93.6 \\
\hline
\end{tabular}

출처: Young-Sun Ra, et. al., (2012), p. 29 재인용

1970 년대 이러한 노력의 결과 과학기술관련 대학에 입학생 수가 1973년 26,000명에서 1980년 58,000 명으로 두 배 이상 증가하였다. 같은 기간동안 기술계 고등학교 입학생은 두 배, 기술 전문대 입학생은 5 배 증가했다. 정부의 노력으로 22 개의 기술훈련센터가 만들어져 이를 통해 약 12,000 명의 기능인력이 이 기간 동안 배출되었다. ${ }^{19)}$

이시기 고도산업화 기간 동안 한국의 직업훈련 제도는 몇 단계를 거쳐 변화되었다. 1970년대는 산업 및 경제의 도약기에 해당하는 시기로 사업내 직업훈련 의무 제도가 도입되어 새로운 산업의 육성을 위해 필요한 대규모 기능인력 수요를 충족시키는 역할을 하였다. 다른 한편으로 외국의 원조 자금을 이용하여 공공 직업훈련 시설이 설립되기 시작한 것도 이때의 일이었다.

반면 1980년대에는 산유국발 오일쇼크 등으로 인한 경제성장의 둔화로 기능인력에 대한 수요 증가가 둔화되는 상황이었지만, 기능인력에 대한 수요는 양적 확대보다는 질적 고도화로 방향이 변하기 시작하였다. 기능인력의 공급 분야의 다양성을 높이는 한편 기능수준을 전반적으로 높이려는 노력이 강화되었다. 동시에 기업 내에서 현직 노동력의 기능수준을 높이는 노력의 필요성도 더욱 높아졌다. ${ }^{20)}$ 결국 1980 년대에는 그 이전 시기와는 달리 산업인력에 대한 공급이 양적 확대보다는 질적 수준을 높이고 공급분야를 다양화하는 방향으로 점차 변화되었다고 볼 수 있다.

18) 전게서, p. 30

19) 전게서, p. 27

20) 전게서, p. 60 
$<$ 표 4> 한국 고도 산업화 시기 직업훈련제도의 변화

\begin{tabular}{|c|c|c|c|}
\hline & 1960년대 & 1970년대 & 1980년대 \\
\hline $\begin{array}{l}\text { 경제발전 } \\
\text { 단계 }\end{array}$ & 제1차, 제2차 경제개발계획 & $\begin{array}{l}\text { 제 } 3 \text { 차, 제 } 4 \text { 차 경제개발계 } \\
\text { 회; 산업의 도약과 중화학공 } \\
\text { 업 육성 }\end{array}$ & $\begin{array}{l}\text { 제5차, 제6차 경제개발계획; 개 } \\
\text { 방과 안정화 }\end{array}$ \\
\hline $\begin{array}{l}\text { 일인당 } \\
\text { 소득 수준 }\end{array}$ & $\$ 80$ & $\$ 254 \longrightarrow \$ 1,676$ & $\$ 1,645 \longrightarrow \$ 5,418$ \\
\hline $\begin{array}{l}\text { 직업훈련 } \\
\text { 관련 입법 }\end{array}$ & 직업훈련법(1967) & $\begin{array}{l}\text { 직업훈련특별조치법(1974), } \\
\text { 기초직업훈련법(1976), } \\
\text { 직업훈련진흥기금법(1976) }\end{array}$ & 기초직업훈련법 4차 수정(1987) \\
\hline $\begin{array}{c}\text { 노동력 } \\
\text { 수요의 } \\
\text { 변화와 이에 } \\
\text { 대한 대응 }\end{array}$ & $\begin{array}{l}\text { 경공업 육성에 필요한 단순 } \\
\text { 공 수요 증가 } \\
\longrightarrow \text { 일반 학교나 직업훈련 } \\
\text { 기관 설립을 통한 기능공 } \\
\text { 공급, 직업훈련보조금 제 } \\
\text { 도 도입 }\end{array}$ & $\begin{array}{l}\text { 중화학공업 육성에 따라 숙련 } \\
\text { 기능공 대량 부족 } \\
\longrightarrow \text { 이농인구의 급증으로 인한 } \\
\text { 비숙련노동력의 공급의 확대, } \\
\text { 직업고등학교 설립, 공립 직업 } \\
\text { 훈련기관 및 의무훈련제도 확 } \\
\text { 대, 직업훈련세 도입 }\end{array}$ & $\begin{array}{l}\text { 사업 내 직업훈련 수요 감소; } \\
\text { 공립 직업훈련제도 강화; } \\
\text { 국립직업훈련원 설립(1982), } \\
\text { 고수준 기능공 양성과정 } \\
\text { (석사급) 도입 }\end{array}$ \\
\hline
\end{tabular}

출처: Young-Sun Ra, et. al., (2012), p. 60 61

\section{5. 개도국에 대한 시사점}

\section{1) 산업화를 통한 일자리 창출의 필요성}

\section{(1) 개도국의 빈곤감소를 위한 일자리 창출을 위한 산업 및 기업발전과 연계 필요성}

일자리 창출이 빈곤감소로 이어지는 경로는 긴 우회로이긴 하지만 경제적으로 지속가능성을 높은 방식이다. 하지만 고용의 양 뿐만 아니라 지속가능성, 나아가 임금 수준 등 질적 특성은 관련 기업 및 산업의 발전과 분리할 수 없다. 즉 노동시장에서의 성과와 산업분야에서의 성과는 분리할 수 없다.

산업분야중 제조업은 그 특성상 적어도 개도국에게는 성장 동력으로서의 역할 때문에 특히 중요성이 크다. 중진국을 넘어 선진국으로 이행하는 과정에서 대부분 나라가 제조업 고용이 감소하는 탈산업화를 겪지만, 적어도 경제발전 초기단계에 있는 나라에게 제조업을 중심으로 한 산업의 발전은 일자리 창출, 산업발전, 경제성장, 빈곤감소가 상호작용하는 선순환을 가능하게 하는 주요 동력이다.

(2) 산업발전과 고용발전을 연계하는 정부의 역할

이것은 일자리 창출을 위한 전략이 산업 전략과 분리될 수 없다는 의미이기도 하다. 한편으로는 인력에 대한 수요의 원천인 산업 및 기업의 발전을 위한 넓은 의미의 산업정책이 있어야 하고, 다른 
한편으로는 산업에서 필요로 하는 인력을 양적으로나 질적(구조적)으로 부족함이 없도록 공급하는 인력개발 및 공급 제도 및 정책이 수립되어야 한다.

개도국은 일반적으로 산업발전을 위한 핵심 생산요소, 즉 기술, 인력, 자본이 모두 부족하고 이들 핵심 생산요소를 공급하기 위한 각종 제도와 시장이 제대로 발전되어 있지 못한 것이 일반적 특징이기 때문에 산업발전을 위한 정부의 역할이 클 수밖에 없다. 산업인프라에 대한 투자는 물론, 기술도입 및 확산을 위한 정부의 적극적인 투자, 산업생산의 증가를 위해 필요한 기능인력 양성 투자 등은 산업발전과 고용발전이 연계되도록 하는 정부의 핵심적 역할이었다. 한국과 같이 중화학공업을 육성하기 위한 정책을 편 브라질이 인력개발과 기술개발을 위한 투자에 소홀히 함으로써 경쟁력을 갖춘 중화학산업의 발전에 실패했다는 진단 ${ }^{21)}$ 은 기술 및 인력에 대한 투자가 동시에 진행되지 않고는 지속가능한 산업도 지속가능한 고용도 어렵다는 것을 보여주는 사례이다.

\section{(3) 산업화를 위한 조건의 국별, 시대별 차이를 고려해야 함}

일반적으로 산업이 성장동력의 역할을 할 수 있다고 하더라고 산업화를 위한 제도와 정부정책의 방향은 해당 개도국이 처해있는 대내외적인 조건에 맞게 다양하게 조정되어야 한다. 특히 산업화 초기에 부존자원의 조건은 산업화의 방향에 크게 영향을 미친다. 예를 들면 자원에 대한 의존도가 매우 높은 자원부국의 경우 풍부한 자원이 오히려 산업화의 장애가 되는 '자원의 저주'가 발생하는 경우가 많다는 점은 모든 나라가 동일한 방식으로 산업화에 성공할 수 없다는 것을 알게 해 준다. 이러한 부존자원 조건뿐만 아니라 산업화를 추진할 수 있는 정부의 정책역량도 중요하다. 개도국의 산업발전을 위해서는 상대적으로 강한 정부의 역할이 요구되지만 정부의 정책 역량이 뒷받침되지 않을 경우에는 오히려 정부의 적극적 역할이 성공적 산업화의 걸림돌이 될 수도 있다.

시대적 상황에 따라서도 산업화를 위한 전략이 수정되어야 한다. 오늘날 다국적 기업이 주도하는 국제가치사슬이 확산, WTO 체제로 요약할 수 있는 국제무역 및 경제 질서, 중국이나 인도 등 대규모 국가가 산업 강국으로 부상하는 현실 등은 한국이 산업화를 추진하던 60 70년대와 21세기 초반의 상황을 크게 다르게 만들고 있다. 개도국의 산업화를 위한 조건도 크게 변화되었다.

결국 이런 모든 조건을 고려할 때 개도국 산업화를 통한 일자리 창출과 나아가 빈곤 감소는 결코 쉬운 길이 아니다. 그럼에도 불구하고 몇몇 자원부국을 제외하면 빈곤국에서 중진국으로 가능 과정에서 산업화를 통하지 않고 성공한 사례를 찾기 어렵다는 점에서 어느 정도 불가피한 길이기도 하다. 따라서 시대별, 국별 조건에 맞는 산업발전 전략의 방향을 찾아내고 효과적인 추진 시스템을 구축하는 노력은 빈곤감축을 위한 전 세계적인 노력의 한 요소라는 점에서 중요하다.

21) Mauricio Canedo Pinheiro(2013), “The Process and Policy of Brazil's HCl Drive”, in Do Hoon Kim, et. al., (2013), International Comparisons of Processes and Policies for Developing Heavy and Chemical Industries 


\section{2) 한국의 기능인력 공급 제도 및 정책이 주는 시사점}

이러한 관점에서 앞에서 소개한 한국의 기능인력 공급 제도 및 정책도 고용 확대 및 구조개선 노력을 위한 노력에서 유용한 시사점을 제공할 수 있다.

(1) 국가 경제개발 계획과 인력훈련 시스템의 긴밀한 연계

산업화와 산업고도화가 진전되는 과정이 핵심 생산요소의 공급에서 병목현상 없이 이루어지기 위해서는 인력공급이 양과 질에서 부족함이 없이 적절하게 이루어져야 한다. 한국에서는 세계사에서 유래가 드문 속도로 산업의 고도화가 이루어졌듯이 인력개발에 대한 투자도 양적으로 비약적으로 확대되었을 뿐만 아니라 질적으로도 빠르게 개선되었다. 특히 1970년대 중화학공업화 경험에서 볼 수 있듯이, 신규 산업을 도입할 경우 대규모의 시설투자뿐만 아니라 생산에 필요한 기능 인력을 양성하기 위해 선제적으로 투자가 이루어졌다는 점은 산업발전 전략과 인력양성 전략이 유기적으로 결합된 좋은 사례이다.

\section{(2) 산업계의 수요 변화에 대응한 공급의 적절한 조정}

한국은 산업계의 수요에 대응하여 필요 인력을 단기간 내에 공급할 수 있는 인력훈련제도를 발전시켰다. 한편으로는 직업교육제도를 통하여 일반적이고 기초적인 지식을 제공하는가 하면 다른 한편으로 특정 산업에 맞춰진 대규모 기능 인력을 단기간에 공급할 수 있는 훈련제도도 발전시켰다. 이렇게 단기 훈련을 통한 기능인력 공급구조는 산업구조의 고도화에 따라 빠르게 변화되었다. 그만큼 산업계의 수요 변화가 빠른 속도로 반영되어 인력공급이 이루어졌다는 것을 의미한다.

$<$ 그림 10> 주요 분야별 훈련생 추이

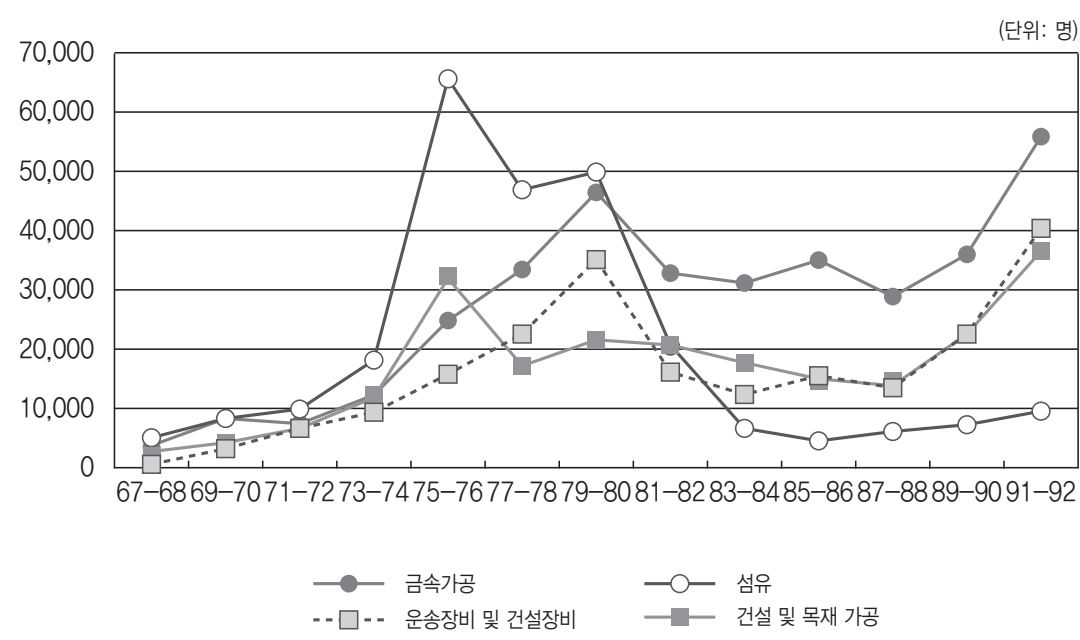

출처: Young-Sun Ra, et. al., (2012), p. 78에서 재인용 


\section{(3) 기능인력 공급에서 정부와 민간의 역할 분담}

산업화를 위한 다른 정책 분야와 마찬가지로 기능인력 공급에서도 정부와 민간의 적절한 역할 분담이 매우 중요하다. 양자 간 분업의 내용도 경제발전 수준에 따라 변화되어야 한다.

산업화 초기 단계에는 정부 및 공공부문의 역할이 상대적으로 큰 것이 자연스러울 것이다. 그러나 한국의 경우 초기 단계에도 민간부문이 스스로 기능인력 훈련에 투자하도록 각종 지원제도가 도입되었다. 따라서 민간부문에 기능인력 훈련 의무를 부과하는가 하면 민간기업의 기능인력 훈련에 대한 보조금도 지급했다. 보다 중요하게는 5개년 경제개발계획과 연계하여 과학-기술발전 계획은 물론 인적자원개발 5 개년 계획도 동시에 입안하여 포괄적인 산업발전 전략을 추진하였다.

이러한 과정을 통해 경제발전과 함께 민간부문의 역량이 축적되면서 기능인력 훈련의 기능도 민간부문 중심으로 변화되었다. 정부의 직접적인 개입이 축소되고 민간부문이 활동을 촉진하고 유도하는 역할이 정부의 주요 기능이 되었다.

오늘날 많은 개도국이 산업화나 산업다각화를 정책 우선순위에 두고 있다는 점을 고려할 때, 지속가능한 고용창출을 위해서는 이러한 산업 전략에 맞춘 기능인력 공급 시스템, 특히 직업훈련 제도를 정비할 필요가 있다. 기능 인력은 산업발전을 위해 필수불가결하면서 시장에만 의존하여 공급하기 어려운 요소이기 때문이다. 물론 기능 인력의 공급도 경제발전이 진행됨에 따라 양적으로나 질적으로 조정되어야 한다.

한국에서는 직업훈련기관과 직업교육기관이 병존하는 이원적 시스템이 특징이었지만 다른 개도국은 각국의 조건에 맞는 적절한 시스템을 찾아낼 필요가 있다. 산업기반이 아직 취약한 저개발국에서는 기초교육을 통해 기초기술을 축적하는 노력이 더욱 필요할 것이다. 반면 산업화가 어느 정도 진전되어 노동자들도 어느 정도 기본적 숙련이 축적된 단계라면 보다 고도화된 직업교육 및 훈련 제도가 개발되어야 할 것이다.

결국 산업발전을 위한 일자리 창출 과정은 끊임없이 산업 및 고용 차원에서 구조변화를 예견하고 준비하며, 예견하지 못한 변화들에 대응하여 해결책을 찾아내는 과정이다. 한국의 경험을 포함하여 과거의 성공적 사례가 하나의 지침이 될 수는 있지만 각 나라가 시대와 상황에 맞는 새로운 해결책을 찾아내야 하는 발견의 과정이다. 따라서 장기적 관점에서 볼 때 사회의 학습의지와 역량이 이 과정에서 성공하는 나라와 그렇지 못한 나라의 가장 큰 차이가 될 수 있다. 


\section{<참고문헌>}

박용현(2014), “기업연구소 3만개, 혁신의 패러다임 바꾸자", 매일경제신문 2014년 5월 8 일자

산업통상부(2014), "2011년도 노동생산성 국제비교"

정택수(2013), “직업능력개발제도의 변천과 과제”, 산업연구원 회의자료

주동주 외(2013), 한국의 산업분야 ODA 역량과 추진 방안, 산업연구원, 세계경제사회연구원, 연구보고서 2013-696

Ernst, D. (2001), "Global Production Networks and Industrial Upgrading: a KnowledgeCentered Approach", East-West Center Working Paper no. 25

Hobday, M.(1994), "Export-led technology development in the four Dragons: the case of electronics”, Development and Change, vol. 25.

Kang, D. Y. (2014), "Re-industrialization of the Korean economy: facts, causes, and implications", KRCS and CNRS, 미래에의 전략적 대응, 국제세미나 발표자료

MGI(2012), Manufacturing the future: the next era of global growth and innovation

Pinheiro, M. C. (2013), “The Process and Policy of Brazil's HCI Drive”, in Do Hoon Kim, et. al., (2013), International Comparisons of Processes and Policies for Developing Heavy and Chemical Industries

Ra, Young-Sun et. al., (2012), Vocational training system for a skilled workforce, 2011 modulization of Korea's Development Experience

Rowthorn,R. and R. Ramaswamy(1997), “Deindustrialization: causes and implications”, IMF working paper, WP/97/42

Trenenna, F. (2009), "Characterising deindustrialization: an analysis of changes in manufacturing employment and output internationally", Cambridge Journal of Economics, 33

Wortzel, L. H. and H. W. Wortzel(1981), "Export marketing strategies for NICs and LDC-based firms", Columbia Journal of World Business, 16(1) 